\title{
EU Common Values in the EU-Ukraine Association Agreement: Anchor to Democracy?
}

\author{
Roman Petrov \\ Mohyla Academy, \\ National University of Kyiv \\ 2 Skovorody vul., \\ Kyiv 04070, Ukraine \\ E-mail: romanpetrov23@gmail.com
}

\begin{abstract}
This article analyses the Association Agreement (AA) between the $E U$ and Ukraine. It argues that this agreement constitutes a new legal framework which has the objective to establish a unique form of political association and economic integration, characterised by three specific features: comprehensiveness, complexity and conditionality, and to promote EU values into the legal systems of Ukraine. The article studies substantive and procedural means of promotion and protection of $E U$ values in the AA. The article scrutinises objectives, institutional framework and mechanisms of enhanced conditionality and legislative approximation in the AA. In addition, the means to protect EU values (the EU's response to security conflicts in Ukraine) are discussed.
\end{abstract}

Keywords: Association Agreement, common values, European Union, legislative approximation, Ukraine

\section{Introduction}

Entering into force of the EU-Ukraine Association Agreement (AA) in September 2017 led to the consideration of the issue of promotion of the EU common values into the legal system of Ukraine. Yet there is no straightforward clarification of this issue because the AA is the first framework international agreement in the modern history of Ukraine that implies its deep and far-reaching integration into the legal order of a supranational international organisation. The objective 
of promoting EU common values occupies a central place among the objectives of the AA. EU common values underpin mutual "close and lasting relationship" and the parties share "common history and common values" and are "committed to implementing and promoting" them (EU-Ukraine AA, 2014).

Taking the above as a starting point, the aim of this paper is to consider three issues. We look, first of all, at the objectives and specific features of the AA between the EU and Ukraine. Second, we look at the scope of EU policy of enhanced conditionality applied therein. Third, we study the means of promotion of EU common values into the legal system of Ukraine.

\section{Objectives and specific features of the Association Agreement with Ukraine}

The AA is the most voluminous and ambitious among all EU association agreements with third countries ( 7 titles, 28 chapters, 486 articles, 43 annexes on about 1,000 pages). This is a comprehensive mixed agreement based on Article 217 of the TFEU (association agreements) and Articles 31(1) and 37 of the TEU (EU action in area of Common Foreign and Security Policy). There are many novelties introduced to these agreements. The most prominent of them are the strong emphasis on comprehensive regulatory convergence between the parties and possibility for the application of the vast scope of the EU acquis within the Ukrainian, Moldovan and Georgian legal orders. Of particular significance of the AA is the ambition to set up a Deep and Comprehensive Free Trade Areas (DCFTA), leading to gradual and partial integration of Ukraine into the EU Internal Market. Accordingly, the AA belong to the selected group of 'integration-oriented agreements', i.e. agreement including principles, concepts and provisions which is to be interpreted and applied as if the third country is part of the EU. It is argued that the AA is unique in many respects and, therefore, provides a new model of integration without membership.

The AA is characterised by three specific features: comprehensiveness, complexity and conditionality. The AA is comprehensive framework agreement which embraces the whole spectrum of EU activities from setting up deep and comprehensive free trade areas (DCFTA) to cooperation and convergence in the field of foreign and security policy as well as cooperation in the area of freedom, security and justice (AFSJ) (Van Elsuwege in Van der Loo, Van Elsuwege \& Petrov, 2014). 
The complexity of the AA reflects the high level of ambition of Ukraine to achieve economic integration in the EU Internal Market through the establishment of the DCFTAs and to share principles of the EU's common policies. This objective requires comprehensive legislative and regulatory approximation including advanced mechanisms to secure the uniform interpretation and effective implementation of relevant EU legislation into national legal order of Ukraine. In order to achieve this objective, the AA is equipped with multiple specific provisions on legislative and regulatory approximation including detailed annexes specifying the procedure and pace of the approximation process for different policy areas in more than 40 annexes and based on specific commitments and mechanisms identified in both the annexes and specific titles to the agreement.

Furthermore, the AA is founded on a strict conditionality approach, which links the third country's performance and the deepening of its integration with the EU. In addition to the standard reference to democratic principles, human rights and fundamental freedoms as defined by international legal instruments (Helsinki Final Act, the Charter of Paris for a New Europe, the UN Universal Declaration on Human Rights and the European Convention on Human Rights and Fundamental Freedoms) (Art. 2 of the EU-Ukraine AA), the AA contains common values that go beyond classical human rights and also include very strong security elements such as the "promotion of respect for the principles of sovereignty and territorial integrity, inviolability of borders and independence, as well as countering the proliferation of weapons of mass destruction, related materials and their means of delivery" (Art. 2 of the EU-Ukraine AA).

Apart from the more general 'common values' conditionality, the AA contains a specific form of 'market access' conditionality, which is explicitly linked to the process of legislative approximation. Hence, it is one of the specific mechanisms introduced to tackle the challenges of integration without membership. Of particular significance is a far-reaching monitoring of Ukraine's efforts to approximate national legislation to EU law, including aspects of implementation and enforcement (Art. 475(2) of the EU-Ukraine AA). To facilitate the assessment process, the government of Ukraine is obliged to provide reports to the EU in line with approximation deadlines specified in the Agreements. In addition to the drafting of progress reports, which is a common practice within the EU's pre-accession strategy and the ENP, the monitoring procedure may include "on-the-spot missions, with the participation of EU institutions, bodies and agencies, non-governmental bodies, supervisory authorities, independent experts and others as needed." (Art. 475(3) of the EU-Ukraine AA). 


\section{Enhanced conditionality in the Association Agreement with Ukraine}

Conditionality is one of the key strategic tools of the ENP and it is, therefore, no surprise that this instrument also occupies a prominent place in the AA. Two different forms of conditionality can be distinguished in these agreements. On the one hand, the AA include several provisions related to Ukraine's commitment to the common European values of democracy, rule of law and respect for human rights and fundamental freedoms ('common values' conditionality). On the other hand, the part on the DCFTAs is based on an explicit 'market access' conditionality implying that Ukraine will only be granted additional access to a section of the EU Internal Market if the EU decides, after a strict monitoring procedure, that these countries successfully implemented its legislative approximation commitments. Both forms of conditionality bear some revolutionary features in comparison to other external agreements concluded between the EU and third countries (Petrov, 2016; Kerikmäe \& Chochia, 2016).

\section{1 'Common values' conditionality}

International agreements concluded on behalf of the EU include standard conditionality clauses. In general, an 'essential element clause' defining the core common values of the relationship is combined with a 'suspension' clause including a procedure to suspend the agreement in case of violation of those essential elements. Such a mechanism is also included in the AA (Art. 2 in conjunction with Art. 478 of the EU-Ukraine AA). Yet, the common values conditionality in the AA differs from similar provisions included in, for instance, the SAA with the Western Balkans. First, in addition to the standard reference to democratic principles, human rights and fundamental freedoms as defined by international legal instruments (Helsinki Final Act, the Charter of Paris for a New Europe, the UN Universal Declaration on Human Rights and the European Convention on Human Rights and Fundamental Freedoms), a specific reference to human rights and fundamental freedoms is included in the AA's provisions on "dialogue and cooperation on domestic reform" and in the AA's provisions dealing with EU cooperation with Ukraine on justice, freedom and security (Art. 7 of the EU-Ukraine AA). Second, the essential elements of the AA contain common values that go beyond classical human rights and also include very strong security elements such as the "promotion of respect for the principles of sovereignty and territorial integrity, inviolability of borders and independence, as well as countering the proliferation of weapons of mass destruction, related 
materials and their means of delivery". Third, "the principles of free market economy" as well as a list of other issues such as "rule of law, the fight against corruption, the fight against the different forms of trans-national organised crime and terrorism, the promotion of sustainable development and effective multilateralism" are not included in the definition of essential elements. Rather, they are considered to "underpin" the relationship between the parties and are "central to enhancing" this relationship. In other words, a distinction is made between hard core common values related to fundamental rights and security and a range of other general principles that are deemed crucial for developing closer relations but which cannot trigger the suspension of the entire agreement (Art. 478 of the EU-Ukraine AA).

\section{2 'Market access' conditionality}

Apart from the more general 'common values' conditionality, the AA entail a specific form of 'market access' conditionality, which is explicitly linked to the process of legislative approximation in Ukraine. Hence, it is one of the specific mechanisms introduced to tackle the challenges of integration without membership. Of particular significance is a far-reaching monitoring of these countries' efforts to approximate national legislation to EU law, including aspects of implementation and enforcement (Art. 475(2) of the EU-Ukraine AA). To facilitate the assessment process, the Ukrainian government is obliged to provide reports to the EU in line with approximation deadlines specified in the Agreement (Art. 475(3) of the EU-Ukraine AA). In addition to the drafting of progress reports, which is a common practice within the EU's pre-accession strategy and the ENP, the monitoring procedure may include "on-the-spot missions, with the participation of EU institutions, bodies and agencies, nongovernmental bodies, supervisory authorities, independent experts and others as needed." Arguably, the latter option is a new and far-reaching instrument introduced precisely to guarantee that legislative approximation goes beyond a formal adaptation of national legislation (Van der Loo, 2015). 


\section{Protection of EU Values in the Association Agreement with Ukraine via EU's sanctions towards third countries}

Principles of sovereignty and territorial integrity, inviolability of borders and independence are considered as core values of the AA and must be shared and respected by the EU and Ukraine. Furthermore, in case of the EU-Ukraine AA, these principles constitute essential elements of the agreement.

The overall security situation in the EU's neighbouring countries for the last decade has gradually deteriorated. Currently Moldova and Georgia have unresolved border security conflicts either with other EU's neighbouring countries or with third countries (mainly with the Russian Federation). Ukraine has been plunged into flames of a bloody civil conflict since April 2014.

Moldova experiences a prolonged conflict with its breakaway part Transnistria (so called Pridnestrovian Moldovan Republic). This territory is not recognised by any of the UN members and formally constitutes part of the Republic of Moldova (Transnistria autonomous territorial unit with special legal status). However, de facto, Transnistria is an independent state with strong presence of Russian military troops. The EU is engaged in solving the Transnistrian conflict via the European Border Assistance Mission to Moldova and Ukraine (EUBAM). This structure, as part of the EU Common Security and Defence Policy, helps to control traffic on borders between Moldova and Ukraine around Transnistria in order to prevent illegal movements of people and goods from and to Transnistria (Kurowska \& Tallis, 2009).

Georgia went through a military conflict with Russia over the breakaway areas of Abkhazia and South Ossetia. The conflict took place in August 2008 and led to many casualties and loss of control of Georgia over Abkhazia and South Ossetia. Currently Russian military troops are stationed in Abkhazia and South Ossetia and de facto control their territories.

The EU played quite a modest role in settling the conflict in the Caucasus allowing some EU Member States to lead the peace process in the region (Vasilyan, 2011). No sanctions were applied by the EU in the aftermath of the Georgian-Russian conflict.

However, the next security challenge within the country which was on the road of signing the AA compelled the EU to act and to apply sanctions against one of the leading geopolitical players on the European continent-the Russian Federation. It happened after the self-proclaimed authorities of the Autonomous Republic 
of Crimea held an unrecognised referendum under Russian military presence in March 2014. As a result of this, the integral part of Ukraine - the Autonomous Republic of Crimea and the city of Sevastopol-were annexed by the Russian Federation and incorporated by the Russian Federation as own federal subjects on March 21, 2014. The fact of annexation is not recognised by Ukraine and the United Nations (UN, 2014) and is universally considered as blatant violation of international public law by the Russian Federation (Marxsen, 2014).

Following the turbulent events in Crimea the EU decided to apply wide-scale sanctions against Russia. The EU sanctions led to a complete halt in the EURussia relations (suspension of bilateral talks on visa matters and on new EURussia agreement, cancellation of the EU-Russia summit) and to imposing measures against "certain persons responsible for actions which undermine or threaten the territorial integrity, sovereignty and independence of Ukraine" (travel bans and asset freezes). The list of these persons is constantly increasing and covers leading Ukrainian, Russian and Crimean politicians related to the fact of the Crimea's annexation. The EU had to extend the scope of sanctions against Russia after the security situation in Ukraine had drastically deteriorated by the end of the summer 2014. The world was shocked when Malaysia Airline flight MH17 was shot down above the part of Eastern Ukraine controlled by proRussian separatists. This incident caused the loss of 298 lives and drastically deteriorated the security situation in the region and in the EU. Bloodshed conflict between Ukraine and armies of self proclaimed 'peoples republics' of Donetsk and Lugansk led to several thousand casualties and about a million refugees from the East of Ukraine (UN (Report on the human rights situation in Ukraine in 2017). The EU Member States had to speak with one voice in order to show their solidarity against direct Russian involvement into civil conflict in Ukraine. As a result the EU Member States agreed on new level of sanctions against Russian and Ukrainian officials and nationals involved in supporting the separatists' movement in the Donbass region of Ukraine. Hitherto, the EU's sanctions against Russia concerned the following issues: diplomatic measures (cancellation of the EU-Russia political dialogue and dismantling of G8); restrictive measures (asset freezes and visa bans of persons and entities responsible for actions against Ukraine's territorial integrity); restrictions for Crimea and Sevastopol; "economic" sanctions against Russia (prohibition of exports of arms, energy and military related technologies and dual use goods, freezing economic cooperation).

The EU sanctions were issued upon the unanimous decision of all the EU Member States on basis of Article 215 of the TFEU as part of the Common Foreign and Security Policy (CFSP). This fact represents evident solidarity of 
all EU Member States facing a violation of territorial integrity of one of its nearest neighbours which is about to enter into association relations with the EU.

It is hoped that the procedure of political dialogue and institutional framework of the AA will be effectively used to protect the principles of sovereignty and territorial integrity, inviolability of borders and independence considered as core values of the AA.

\subsection{Constitutional amendments caused by the implementation of the AA}

One of the first 'post-Maidan' constitutional amendments took place in June 2016 when the Verkhovna Rada adopted the Law of Ukraine 'On Amending the Constitution of Ukraine (As to Justice)' (No. 1401-VIII, VVR (2016) No. 28). These constitutional amendments were proposed by President Poroshenko in light of the fight against corruption and the independence of judiciary in Ukraine. The constitutional amendments sparked considerable public debate in Ukraine and beyond. Externally, the European Commission for Democracy through Law (Venice Commission) two times scrutinised the draft amendments for their compliance with European standards and issued several important reservations. Internally, on the one hand, the draft amendments were criticised for giving extended powers to the President of Ukraine to influence the appointment of judges, narrowing the scope of judges' immunity, and for keeping a complicated system of specialised courts in Ukraine. On the other hand, the position of the Office of the President of Ukraine was that the constitutional amendments were crucial to achieve the objectives of the EU-Ukraine AA regarding sharing common values, fighting corruption and improving access to judiciary. In particular, the constitutional amendments ensure that Ukraine observes the essential elements of the EU-Ukraine AA (respect for the principle of the rule of law) and meets the objectives of Title III of the EU-Ukraine AA on justice, freedom and security which call Ukraine to consolidate the rule of law, to improve the efficiency of the judiciary, to safeguard its independence and impartiality, and to combat corruption (Article 14 of the EU-Ukraine AA).

The official position of the EU institutions regarding the constitutional reform in Ukraine was rather supportive. The annual report on the progress of implementation of the EU-Ukraine AA hailed the constitutional amendments of 2016 as legislation, which 'strengthen judicial independence and [reorganises] the court system, by streamlining the judicial instances (from four to three) and by subjecting the sitting judges to examinations and mandatory electronic asset declarations' (Joint Staff Working Document, SWD (2016) 446 final). Furthermore, it must be 
acknowledged that the most recognised impact of the EU-Ukraine AA (Article 8 of the EU-Ukraine AA) on the constitutional reform in Ukraine can be seen in revised Article 124 of the Constitution wherein it is stated that 'Ukraine may recognise the jurisdiction of the International Criminal Court as provided for by the Rome Statute of the International Criminal Court'. This amendment overrules the Decision of the Constitutional Court of Ukraine from 2001, which explicitly considered the recognition of the jurisdiction of the International Criminal Court as incompatible with the national Constitution and, therefore, made the ratification of the former by the Ukrainian Parliament impossible (Decision of the Constitutional Court of Ukraine on the Statute of the International Criminal Court, Case No. 1-35/2001). The wording of revised Article 124 of the Ukrainian Constitution opens up a possibility for the Ukrainian Parliament to ratify the Rome Statute in the near future. However, the ratification of the Rome Statute is likely to be postponed until the eventual implementation of the 'Minsk II Agreement' regarding the military conflict in the East of Ukraine (Donbass area) caused by the aggression of Russia in Ukraine. In particular, the sides of the conflict must ensure the effective ceasefire, effective control by Ukraine of its eastern border with Russia and guarantee the amnesty of illegally armed belligerents. These actions must take place before the ratification of the Rome Statute in order to avoid entrenching a legal war between the government of Ukraine and the Russian government and governments of the self-proclaimed separatist republics in the East of Ukraine (Bentzen, 2016). Another test on Ukraine's devotion to the EU's common values as enshrined in the EU-Ukraine AA took place in September 2017 when the Verkhovna Rada adopted the new education law. It immediately sparked controversial reception and protests by representatives of national minorities (mainly the Hungarian minority) in Ukraine (Law of Ukraine "On Education", No. 2145-VIII, VVR (2017) No. 38-39). This law foresees the reduction of scope of instruction in mother tongue of a national minority at the secondary education level. According to the new education law only primary school education can be given in mother tongue of a national minority in Ukraine. Secondary and higher education must be offered only in official language (Ukrainian) with possibility to study the mother tongue as one of the courses. The Hungarian government fiercely protested against the new educational law on the grounds of violating rights of the Hungarian minority in Ukraine (Hrynevych, 2018). Furthermore, the Hungarian government considered the Ukrainian education law in conflict with objectives and human rights commitments of Ukraine in the EU-Ukraine AA. In order to prevent the escalation of tension with some of the EU Member States, the Ukrainian authorities submitted the Article 7 of the education law to the assessment of the Venice Commission. In the assessment, issued on 11 December 2017, the Venice Commission noted the vague nature of relevant 
provisions of the national education law and recognised narrowing the access of national minorities to obtaining secondary education in their mother tongue. The Venice Commission recommended adopting further implementing legislation in order to ensure sufficient level of teaching in languages of the EU Member States in Ukraine. However, the Venice Commission recognised the discrimination of national minorities' languages that are not official languages of the EU (Russian) and called Ukraine not to endanger "the preservation of the minorities' cultural heritage and the continuity of minority language education in traditional schools" (Statement of the Ministry of Education and Science of Ukraine, 2017). The Ukrainian government welcomed the findings of the Venice Commission and agreed to follow most of them in the course of drafting and adopting further education legislation and to ensure the transitional period of the implementation of the education law till 2020 (Statement of the Ministry of Education and Science of Ukraine on the findings of the Venice Commission, 11 December 2017). Meanwhile, the EU's reaction to the language issue in the education law and its compatibility with the objectives of the EU-Ukraine AA remains neutral (Joint Staff Working Document, SWD (2017) 376 final). However, it is possible that the Venice Commissions' recommendations may be taken on board by the EU institutions and become the part of the conditionality requirements on behalf of the EU towards Ukraine in the process of further implementation and application of the EU-Ukraine AA.

However, the Ukrainian courts have not yet recognised (have mainly avoided the recognition of) the direct effect of provisions of the EU-Ukraine AA in their decisions. In particular, the issue of direct effect of the EU-Ukraine AA may find a particular relevance in case of possible litigation on correspondence of Ukrainian laws and other legal acts to the objectives, principles and 'essential elements' of the EU-Ukraine AA before the Constitutional Court and general courts. Among the most recent examples are the Executive Order of the President of Ukraine on banning the Russian social networks (on the matter of national security and sanctions against the Russian Federation caused by the annexation of Crimea in 2014 and military aggression in the East of Ukraine) (Executive Order of the President of Ukraine on 15 May 2017) and Law of Ukraine on banning the St. George (Guards') Ribbon. It was widely used by paramilitary separatist groups and Russian army's units in the Donbass area and during the annexation of Crimea and, therefore, may be considered as propaganda of the Russian military aggression in Ukraine (Laws of Ukraine 'Ban on production and propaganda of the St. George (Guards') Ribbon' and 'On Vygotovlenya i Propagandy Georgievskoy (gvardiyskoy) Strychky', 16 May 2017). However, these legislative acts raise some concerns regarding their compliance with the objectives of the EU-Ukraine AA, in 
general, and freedom and expression and the principle of proportionality (as they are applied and interpreted within the ECHR and the EU Charter of Fundamental Rights), in particular (Van Elsuwege, 2017).

\section{Concluding remarks}

Taking into account the comprehensive nature of the agreement and the underlying conditionality approach, the AA occupies a unique position within the network of bilateral agreements concluded between the EU and third countries and anchors Ukraine to the EU common values and internationally recognised democratic freedoms.

The EU-Ukraine AA is an innovative legal instrument in the EU's external relations practice based on comprehensiveness, complexity and conditionality. These features are central in ensuring effective and successful promotion of EU values into the legal system of Ukraine. The AA employs various substantive and procedural means of promotion and protection of EU values which have significantly impacted the constitutional and legal system of Ukraine. Security challenges, which happened in Ukraine as well as in other countries of the Eastern Partnership (Moldova, Georgia, Armenia and Azerbaijan), emphasise the urgent need not only to declare and to promote EU values like the principles of sovereignty and territorial integrity, inviolability of borders and independence but also to protect them by means of restrictive measures against third countries that break the international legal order and to deepen cooperation between the EU and the countries of the Eastern Partnership in area of the CFSP.

The EU-Ukraine AA serves as a template for further political and economic reforms in all the countries of the EaP. The obligation to share the EU's common democratic values will imply regular monitoring by the EU institutions. Thereby this should prevent Ukraine and other countries of the Eastern Neighbourhood from undemocratic practices. The new joint institutions set up under the framework of the AAs with Ukraine, Georgia and Moldova will help to pursue the programme of approximating the laws with the help of its binding decisions. The process of effective implementation of the AAs will constitute the greatest challenge for Ukraine, Moldova and Georgia. These countries have to prove their adherence to the EU's common democratic and economic values, and ensure the proper functioning of their deep and comprehensive free trade areas. The latter objective may be achieved only under the condition of establishing truly competitive market economies and the adoption of international and EU 
legal standards. Ukraine, Moldova and Georgia will be bound by decisions of the dispute settlement body established by the AAs. Following the widelyused practice in the EU's external agreements the AAs contain so-called "evolutionary" and "conditionality" clauses. These are provisions in the EU's external agreements with specific objectives (for instance, granting a visa-free regime, access to all freedoms of the EU Internal Market), the attainment of which is conditional either on certain actions on behalf of a party to an agreement (such as the elimination of trade barriers and uncompetitive practices) or the effective functioning of democratic and market-economy standards (such as free and fair elections and fighting corruption).

Looking at the pattern of future implementation and application of the EUUkraine AA and its impact on the Ukrainian legal system it can be concluded with a suggestion that the success of this process is threefold. First, the efficient implementation and application of the AA implies further considerable constitutional reforms in Ukraine in order to enhance the direct enforceability of international agreements within the domestic legal system. Second, effective application of the AA requires Ukraine to issue the implementation law that will clarify and prevent all potential challenges of this complicated process. Third, the scope of the EU acquis to be adopted by Ukraine is massive and covers not only EU laws but EU fundamental principles, doctrines and the ECJ case law. Ukrainian civil servants and judges will require in-depth training in EU law in order to be able to apply the EU acquis in their everyday activities. In case these challenges are successfully met, Ukraine could claim fruits of closer European integration and engage into an expanding European legal space.

Prof. Dr. Roman Petrov is Head of Jean Monnet Centre of Excellence (since 2011) and Jean Monnet Chair in EU Law at the Mohyla Academy, National University of Kyiv (since 2010). He lectured the very first Jean Monnet Module in EU law in Ukraine at the Donetsk National University. He conducted post-doctoral research as Max Weber Fellow at the European University Institute in Florence and was awarded research visiting fellowships at the universities of Heidelberg, Oxford, Ghent, and other international universities. He is a visiting professor at the universities of Latvia and Augsburg, Foreign Chair at the Ghent University (Belgium) and the author of one of the first Ukrainian textbooks on EU Law. Prof. Petrov is active in publishing in internationally recognised peer-reviewed journals. He is the founder and first elected President of the Ukrainian European Studies Association. Areas of Petrov's research and teaching are: EU Law, EU Business Law; EU External Relations Law; Approximation and Harmonisation of Legislation in the EU; Legal Aspects of Regional Integration in the Post-Soviet Area. Prof. Dr. Petrov frequently provides consultancy to state institutions in Ukraine, including the Parliament of Ukraine, Constitutional Court of Ukraine and Ministry of Justice. 


\section{References}

Bentzen, N. (2016), 'Briefing of the European Parliament "Ukraine and the Minsk II agreement: On a frozen path to peace?"' European Parliamentary Research Service, January 2016. Retrieved from http://www.europarl.europa.eu/RegData/ etudes/BRIE/2016/573951/EPRS_BRI(2016)573951_EN.pdf [accessed 20 Jan 2018]

Decision of the Constitutional Court of Ukraine on the Statute of the International Criminal Court, Vysnovok Constitutsiynoho Sudu Ukrainy shodo Vidpovidnosty Constitutsii Ukrainy Rymskomu Statutu Mizhnarodnogo criminalnogo sudu, Case No 1-35/2001, 11.7.2001.

Executive Order (Ukaz) of the President of Ukraine on 15 May 2017, No. 133/2017.

Hrynevych, L. (2018), 'Ukraine Education Law Does Not Harm Minorities', EU Observer, 20 Oct 2017. Retrieved from https://euobserver.com/opinion/139550 [accessed 20 Jan 2018]

Joint Staff Working Document 'Association Implementation Report on Ukraine', SWD (2016) 446 final, Brussels, 9.12.2016.

Joint Staff Working Document 'Association Implementation Report on Ukraine', SWD (2017) 376 final, Brussels, 14.11.2017.

Kerikmäe, T. \& Chochia, A., eds. (2016), Political and Legal Perspectives of the EU Eastern Partnership Policy, Cham: Springer International Publishing. https://doi.org/10.1007/978-3-319-27383-9

Kurowska, X. \& Tallis, B. (2009), 'Border assistance mission: beyond border monitoring?’ European Foreign Affairs Review, vol. 14, no. 1, pp. 47-64.

Law of Ukraine 'Amending the Administrative Code regarding the ban on production and propaganda of the St. George (Guards') Ribbon,' Zakon Ukrainy 'Shodo Zaborony Vygotovlenya i Propagandy Georgievskoy (gvardiyskoy) Strychky,' No. 2031-VIII, VVR (2017) No. 26, 16.5.2017.

Law of Ukraine 'On amending the Constitution of Ukraine (as to justice),' Zakon Ukrainy 'Pro Vnessennia Zmin do Konstitutsii Ukrainy (shodo pravosuddia),' No. 1401-VIII, VVR (2016) No. 28, 2.6.2016.

Law of Ukraine 'On Education,' Zakon Ukrainy 'Pro Osvity,' No. 2145-VIII, VVR (2017), No. 38-39, 5.9.2017.

Marxsen, C. (2014), 'The Crimea Crisis: an international law perspective', Zeitschrift für ausländisches öffentliches Recht und Völkerrecht, vol. 74, no. 2, pp. 367-391. Opinion of the European Commission for Democracy through Law (Venice Commission), 'On the Provisions of the Law of Education of 5 September 2017', Opinion No. 902/2017, Brussels, 11.12.2017. 
Petrov, R. (2016), 'Implementation of association agreements between the EU and Ukraine, Moldova and Georgia: legal and constitutional challenges,' in T. Kerikmäe \& A. Chochia (eds.) Political and Legal Perspectives of the EU Eastern Partnership Policy, Cham: Springer International Publishing, pp. 153-165. https://doi.org/10.1007/978-3-319-27383-9_10

Statement of the Ministry of Education and Science of Ukraine on the findings of the Venice Commission, 11.12.2017. Retrieved from https://mon.gov.ua/ua/news/poziciyamon-shodo-opublikovanogo-visnovku-venecijskoyi-komisiyi-ministerstvodyakuye-za-robotu-komisiyi-ta-gotove-implementuvati-rekomendaciyi [accessed 20 Jan 2018]

UN (2014), UN General Assembly Resolution 68/262 adopted on 27 March 2014 'Territorial Integrity of Ukraine'.

UN (2017), UN Report on the human rights situation in Ukraine in 2017. Retrieved from http://www.ohchr.org/EN/Countries/ENACARegion/Pages/UAReports.aspx [accessed 30 Jan 2018]

Van der Loo, G. (2015), The EU-Ukraine Association Agreement and Deep and Comprehensive Free Trade Area, Leiden: Brill-Nijhoff.

Van der Loo, G.; Van Elsuwege, P. \& Petrov, R., eds. (2014), The EU-Ukraine Association Agreement: Assessment of an Innovative Legal Instrument, EUI Working Papers (Law) 2014/09.

Van Elsuwege, P. (2017), 'Ukraine's ban on Russian social media: on the edge between national security and freedom of expression,'VerfBlog, 6 Feb 2017. Retrieved from http://verfassungsblog.de/ukraines-ban-on-russian-social-media-on-theedge-between-national-security-and-freedom-of-expression [accessed 20 Jan 2018]

Vasilyan, S. (2011), 'The external legitimacy of the EU in the South Caucasus,' European Foreign Affairs Review, vol. 16, no. 3, pp. 341-357. 